\title{
VIEWS AND REVIEWS
}

\section{ACUTE PERSPECTIVE}

\section{David Oliver: Frailty in acute care}

\author{
David Oliver consultant in geriatrics and acute general medicine
}

Berkshire

The National Institute for Health and Care Excellence recently published guidelines on assessing and managing patients with multimorbidity. ${ }^{12}$ These placed distinct and welcome emphasis on frailty - adding momentum to several recent, professionally led good practice resources and guidelines explicitly highlighting the importance of frailty in community and acute care and showcasing services that work. ${ }^{3-8}$

Much nuanced research has been published on frailty as a clinical and physiological entity. ${ }^{9-11}$ It's increasingly prevalent with older age but can affect people in their 50s. To oversimplify: two large schools of thought exist on how to characterise people with frailty. One is the "frailty phenotype" (with at least three of: slow walking speed, muscle weakness, unintentional weight loss, low physical activity, and self reported exhaustion). ${ }^{12}$ The other is an "accumulation of deficits" conception, where the more long term conditions or impairments someone lives with, the higher their frailty score or index. ${ }^{13}$

In either event, people with frailty tend to have poor functional or homeostatic reserve. When presenting to acute care, an illness episode, drug side effect, or metabolic disturbance, which might seem inconsequential in younger, non-frail patients, can present with steep and sudden functional or cognitive decline. ${ }^{14}$

Frailty syndromes are now central to hospital activity — not the geriatrics niche they once were

Very common presentations of acute illness in people with frailty include delirium, acute or sub-acute loss of mobility or functional independence, falls, or a non-specific failure to thrive or cope. These are also commonly associated with admission in frail people who presented to hospital in other ways. ${ }^{3-15}$

Older people with complex comorbidities account for an ever growing proportion of emergency room attendances, admissions, and hospital bed days. A validation study of an electronic frailty index, based on the number of conditions in over 200000 patients in English primary care, has shown that frailty multiplies the risk of acute admission. ${ }^{16}$ Frailty syndromes are now central to hospital activity - not the geriatrics niche they were when hospital medicine was predominantly concerned with single system or infectious diseases in younger people.
We must make our acute care systems fit for frail patients. Simple, pragmatic case finding tools can identify them. Multidisciplinary comprehensive geriatric assessment can improve their outcomes well beyond admission. ${ }^{17}$ Early specialist review and a focus on early rehabilitation and discharge planning can be a win/win for patients and hospitals, reducing bed occupancy and facilitating earlier discharge. ${ }^{18}$

We also need a shift in values and language. These illness presentations are not atypical in older people with frailty. Nor are these patients "social admissions" or "acopic." ${ }^{19}$ When hospital doctors use such ill informed terms, they are effectively failing frail patients who are now their main customers, and for whom more traditional textbooks and curriculums will no longer do.

Competing interests: See www.bmj.com/about-bmj/freelancecontributors/david-oliver.

Provenance and peer review: Commissioned; not externally peer reviewed.

National Institute for Health and Care Excellence. Multimorbidity: clinical assessment and management. 21 Sep 2016. https://www.nice.org.uk/guidance/indevelopment/gidcgwave 0704 .

2 Farmer C, Fenu E, O'Flynn N, Guthrie B. Clinical assessment and management of multimorbidity: summary of NICE guidance. BMJ 2016;354:14843. doi:10.1136/bmj. i4843 pmid:27655884

3 British Geriatrics Society, Royal College of Physicians, Royal College of Nursing, et al. "Silver book": quality care for older people with urgent and emergency care needs. 2012. www.bgs.org.uk/campaigns/silverb/silver_book_complete.pdf.

4 Healthcare Improvement Scotland. Care of older people in hospital standards. Jun 2015. www.healthcareimprovementscotland.org/our_work/person-centred_care/resources/opah_ standards.aspx.

5 Royal College of Physicians of London. Acute care toolkit 3: acute medical care for frail older people. 3 Sep 2015. https://www.rcplondon.ac.uk/guidelines-policy/acute-care-toolkit3-acute-medical-care-frail-older-people.

6 NHS Confederation. Growing old together: sharing new ways to support older people. 2016. www.nhsconfed.org/ /media/Confederation/Files/Publications/Documents/Growing\% 20old\%20together\%20-\%20report.pdf.

7 Oliver D, Foot C, Humphries R. Making health and care systems fit for an ageing population. King's Fund. 2014. www.kingsfund.org.uk/sites/files/kf/field/field_publication_ file/making-health-care-systems-fit-ageing-population-oliver-foot-humphries-mar14.pdf.

8 Acute Frailty Network. Improving services for frail older people. Feb 2015. www. acutefrailtynetwork.org.uk/about-us.

9 Clegg A, Young J, lliffe S, Rikkert MO, Rockwood K. Frailty in elderly people. Lancet 2013;381:752-62.www.thelancet.com/journals/lancet/article/PIIS0140-6736(12)62167-9/ abstractdoi:10.1016/S0140-6736(12)62167-9 pmid:23395245.

10 British Geriatrics Society. Fit for frailty. Jun 2014. www.bgs.org.uk/campaigns/fff/fff_full. pdf. 
11 Stott D, Conroy S, Hubbard RE. Virtual issue: frailty. Age Ageing. www.oxfordjournals. org/our_journals/ageing/frailty_virtual_issue.html.

12 Fried LP, Tangen CM, Walston J, et al. Cardiovascular Health Study Collaborative Research Group. Frailty in older adults: evidence for a phenotype. J Gerontol A Biol Sci Med Sci 2001;56:M146-56.www.ncbi.nlm.nih.gov/pubmed/11253156doi:10.1093/gerona/ 56.3.M146 pmid:11253156

13 Rockwood K. Conceptual models of frailty: accumulation of deficits. Can J Cardiol 2016;32:1046-50.www.onlinecjc.ca/article/S0828-282X(16)30027-7/abstractdoi:10.1016/ j.cjca.2016.03.020 pmid:27402367.

14 Rockwood K. What would make a definition of frailty successful? Age Ageing 2005;34:432-4.http://ageing.oxfordjournals.org/content/34/5/432.full.pdf+html? sid=f5e288d7-a117-4bf6-b13e-78d754cd8c36doi:10.1093/ageing/afi146 pmid:16107450

15 Commission on Hospital Care for Frail Older People. Main report. Health Serv J 2014 Nov 19. https://www.hsj.co.uk/hsj-knowledge/commissions-and-inquiries/frail-older-people/ commission-on-hospital-care-for-frail-older-people-main-report/5076859.article.

16 Clegg A, Bates C, Young J, et al. Development and validation of an electronic frailty index using routine primary care electronic health record data. Age Ageing 2016. http://ageing oxfordjournals.org/content/early/2016/03/03/ageing.afw039.full.
17 Ellis G, Whitehead MA, O'Neill D, Langhorne P, Robinson D. Comprehensive geriatric assessment for older adults admitted to hospital. Cochrane Database Syst Rev 2011;7:CD006211.www.bgs.org.uk/pdf_cms/reference/ellis_cgs_acute_hospital.pdfpmid: 21735403.

18 Silvester KM, Mohammed MA, Harriman P, Girolami A, Downes TW. Timely care for frail older people referred to hospital improves efficiency and reduces mortality without the need for extra resources. Age Ageing 2014;43:472-7.http://ageing.oxfordjournals.org/ content/43/4/472 full pdfdoi:10.1093/ageing/aft170 pmid:24222658.

19 Oliver D. 'Acopia' and 'social admission' are not diagnoses: why older people deserve better. J R Soc Med 2008;101:168-74.www.ncbi.nlm.nih.gov/pmc/articles/PMC2312388/ pmid:18387906.

Published by the BMJ Publishing Group Limited. For permission to use (where not already granted under a licence) please go to http://group.bmj.com/group/rights-licensing/ permissions 